Article

\title{
Corporate Governance Rating and Ownership Structure in the Case of Turkey
}

\author{
Sevin Gurarda ${ }^{1}$, Emre Ozsoz ${ }^{2, *}$ and Abidin Ates ${ }^{3}$ \\ 1 Management Department, Faculty of Business Administration, Gediz University, Seyrek 35665, İZMIR, \\ Turkey; sevin.gurarda@gediz.edu.tr \\ 2 School of Liberal Arts, SUNY-FIT, 27th Street at 7th Ave, New York, NY 10001, USA \\ 3 Management Department, Faculty of Business Administration, Mustafa Kemal University, Serinyol 31120, \\ HATAY, Turkey; abidinates@mku.edu.tr \\ * Correspondence: emre_ozsoz@fitnyc.edu; Tel.: +1-212-217-4929; Fax: +1-212-217-4641
}

Academic Editor: Hong Bo

Received: 2 April 2015; Accepted: 24 March 2016; Published: 15 April 2016

\begin{abstract}
By using corporate governance data on 22 publicly traded Turkish companies we estimate the determinants of corporate governance ratings for these companies with a focus on ownership structure. Our results show that company earnings, financial risk and firm size positively influence the corporate governance ratings (CGR) that Turkish firms receive. In the meantime, we find some weak evidence that family ownership has a negative and foreign ownership has a positive impact on CGR scores.
\end{abstract}

Keywords: corporate governance; corporate governance index; Turkish firms

JEL: G3; F3

\section{Introduction}

Corporate governance as described by Shleifer and Vishny [1] enables investors to get a return on their equity investments by presenting mechanisms to ensure their equity is used efficiently. Implementation of corporate governance measures also enables firms to access capital markets on better terms [2] by providing opportunity to firms to differentiate themselves in the marketplace. This is especially more important in countries where corporate governance practices are weak. One of the biggest challenges for corporations in developing countries like Turkey is sourcing foreign capital. In that regard, implementation of corporate governance practices enables Turkish firms to better access global equity markets. Although corporate governance ratings may not truly reflect corporate governance quality, from a global investor's perspective, CGR ratings are seen as important proxies in assessing whether firms in emerging market countries follow corporate governance practices in line with international standards.

In this paper, we study the determinants of corporate governance rating scores in the Turkish case. Turkey is among the few emerging market economies that have adopted corporate governance measures in line with corporate governance regulations passed in other OECD economies. ${ }^{1}$ The Capital Markets Board of Turkey (CMB) established the Corporate Governance Principles in 2005 and the Turkish Corporate Governance Index is published by the Istanbul Stock Exchange (renamed "Borsa

1 Such as the Organization for Economic Co-operation and Development (OECD) Corporate Governance Principles, UK Corporate Governance and Stewardship Codes, Dodd-Frank Wall Street Reform and Consumer Protection Act, and the Tabaksblat Code in the Netherlands. 
Istanbul" since April 2013). Although inclusion on the index is optional, as of 2014 fifty-two Turkish companies are listed on the index representing $12.32 \%$ of all companies on Borsa Istanbul. It is expected that this number will increase as more Turkish companies will be included in the index.

We are particularly interested in two aspects of Turkish firms on their corporate governance ratings: family-control and foreign ownership. Family-controlled groups of companies are a common characteristic of Turkish business scene. They are usually structured around a bank and could take the form of well-structured conglomerates with professional management. However, family members remain actively involved in strategic and even daily decisions [3]. The cash flow and voting rights in Turkish companies are also "relatively more aligned compared to other family-ownership-dominated insider-system countries" as Demirag and Serter [4] pointed out. As shown by Yıldırım et al. [5], 20\% of board positions and an additional $47 \%$ of directors of Turkish corporations are salaried managers employed by the holding firm or in firms controlled by the same family. The existence of such tight family control may not be a problem in countries with effective regulations and laws for protecting minority shareholders, but it may be pose challenges in an emerging market setting like Turkey where protection of minority shareholders are not as strong. External mechanisms of corporate governance, such as the market for corporate control, do not function in Turkey due to highly concentrated ownership structures [6]. Therefore studying family control and its impact on corporate governance ratings takes a special meaning in the Turkish case.

The prevalence of strong families with controlling corporate stakes is not unique to Turkey. In many emerging market settings (i.e., Brazil, India, Mexico, and Turkey ${ }^{2}$ ) family owned conglomerates hold a significant share in the country's business landscape. In that regard, our study provides a valuable addition to CGR literature in emerging markets.

Another increasingly important aspect of the Turkish corporate landscape is the rising portion of foreign stakes in corporate ownership. As shown by recent studies the effect of FDI on Turkish companies are positive, "so long as foreign companies invest in minority stakes in domestic firms" [8]. Foreign ownership in local companies is also encouraged by policy-makers due to the common notion that foreign ownership increases not only profitability but also accountability. The underlying assumption here is that foreign investors bring much-needed know-how and managerial skills to domestic companies and in return make them more efficient. Although the linkage has been studied in developed market economies, studies that focus on Turkish firms are rare. Research on the effect of foreign ownership on corporate governance ratings in Turkey is still new; this paper in that regard contributes to the existing literature by providing an empirical study.

The outline of this paper is as follows: In the following section, we provide a brief summary of the implementation of corporate Governance Ratings in Turkey; in Section 3 some of the earlier literature on corporate governance ratings and ownership structure is introduced; in Section 4 we describe our data and lay out our methodology; Section 5 provides the results of our estimations; and Section 6 concludes.

\section{Implementation of Corporate Governance Ratings in Turkey}

Although assignment of a CGR score is by no means a representation of a company's corporate governance quality, it is a step in the right direction and serves as an important proxy. The implementation of Corporate Governance Ratings (CGR) in Turkey date back to 2007 (for a discussion on the implementation of the index in Turkey, see Box 1). However, when we compare Turkey's progress in implementing CGR measures in relation to other emerging markets, we observe that Turkey is one of the leaders. Since 2001 only seven other stock exchanges around the world have

2 Ararat et al. [7] report that holding companies held majority control of the 54 out of the 122 companies that constituted the ISE-100 index in 2006 and 2008. The family controlled ownership constitutes about $56 \%$ of the outstanding shares when all ownership stakes under the control of the family are summed. The three largest shareholders hold on average $63 \%$ of the common equity in Turkey. 
launched corporate governance indexes besides Turkey: Brazil, China, Italy, Mexico, Peru, South Africa, and South Korea. Table 1 provides a list of these emerging market and OECD countries where CGR indices are used as well as the number of firms listed on them. As of 2014, the number of corporations listed on the Turkish Corporate Governance Index is higher than those in Mexico and in Peru. We have also witnessed a phenomenal growth in the number of companies listed on the index. In the six years since its inception, the number of firms listed on the index grew more than six-fold (Seven in 2007 versus fifty-two in 2014). As illustrated in Figure 1, as of 2014, 52 companies out of the 422 listed on Borsa Istanbul were included in the index. It is estimated that over time this number will grow even further making the study of corporate governance ratings in the Turkish setting even more important. One of the main reasons for the increased representation in the index is the return to macroeconomic stability in Turkey within the last decade. Macroeconomic stability has been underpinned by public governance reforms, which spilled over to the area of corporate governance and macroeconomic stability. This in return had a positive effect on firms' investment in corporate governance quality [9].

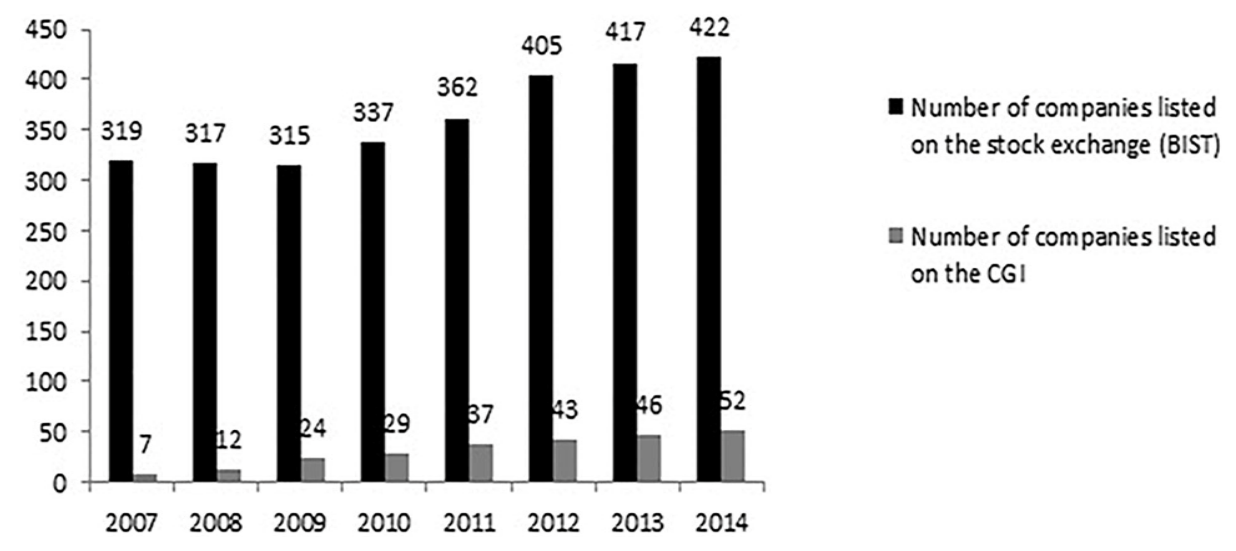

Figure 1. Number of Firms listed on Borsa Istanbul and the Turkish Corporate Governance Index. Source: World Bank and Borsa Istanbul ${ }^{3}$.

Box 1. Implementation of Corporate Governance Index in Turkey.

After CMB's communique on Corporate Governance Rating, Borsa Istanbul published the rules of CGI in
February 2005. In August 2007, the CGI was launched with the inclusion of only five companies. To provide an
incentive for companies to be listed on the index, the annual listing/registration fee was reduced by $50 \%$ for the
first two years of inclusion in the index and by $25 \%$ for the following two years. Companies that remain on the
index beyond this period only pay $90 \%$ of the listing fee.
Companies traded on Borsa Istanbul (except for the companies on the Watchlist, the Turkish equivalent of
Pinksheet Stocks in in the US and C List) are rated by the five rating agencies licensed by the CMB. Evaluated
companies need a minimum corporate governance rating of 7 out of 10 as a whole and minimum of 6.5 for
each evaluation category to be able to be listed in Borsa Istanbul's CGI. The main evaluation categories are
shareholders, disclosure and transparency, stakeholders and board of directors. The weights are as follows:
Shareholders $25 \%$, Disclosure and Transparency $35 \%$, Stakeholders $15 \%$, and Board of Directors $25 \%$. If a
company is rated by a rating agency more than once in a calendar year, the latest rating score is taken into
consideration. In the case of cancellation of one rating agency's rating license by the CMB, the rating evaluations
and scores are cancelled as well. Companies are encouraged to reevaluate their rating scores every year in order
to continue to be listed on the Index.

3 Listed domestic companies are the domestically incorporated companies listed on the country's stock exchanges at the end of the year. 
Table 1. Number of Companies Listed In Corporate Governance Indices in the World.

\begin{tabular}{ccccc}
\hline Country & Index Name & Launch Date & Original Constituents & February 2013 \\
\hline Brazil & Special Corporate Governance Stock Index & 2001 & 12 & 174 \\
China & Corporate Governance Index & 2008 & 199 & 266 \\
Italy & FTSE Italia STAR & 2001 & 20 & 66 \\
Mexico & Indice IPC Sustainable & 2011 & 23 & 29 \\
Peru & Good Corporate Governance Index & 2008 & 9 & 9 \\
South Africa & Socially Responsible Investment Index & 2004 & 49 & 79 \\
South Korea & Korean Corporate Governance Index & 2003 & 50 & 50 \\
Turkey & Corporate Governance Index & 2007 & 7 & 46 \\
\hline
\end{tabular}

Source: The Table is derived from [10] World Bank/IFC study: Raising the Bar on Corporate Governance-A Study of Eight Stock Exchanges Indices.

\section{Literature Review}

Empirical studies that evaluate determinants of CGR usually include firm specific financial measures such as profitability and financial risk (i.e., [11-15]). Borrowing from existing literature any empirical assessment of CGR should include these two measures.

Profitability is usually measured by evaluating return on assets (ROA), return on equity (ROE) and earnings per share [16-21]. Gompers et al. [18] show that better governed US firms have higher valuations but they find that performance indicator, ROE is an insignificant factor. Core et al. [22] argue that ROA is a better measure compared to ROE and find a significant relationship between corporate governance and this performance measure. Contrary to these results [12] show that firms with relatively poor governance are relatively less profitable and pay out less cash to their shareholders. Most of these papers however study the causal link from the direction of profitability to corporate governance. However, there are a growing number of papers that show the link can also be investigated from the perspective of profitability to corporate governance (see [23]). The most common measures used in profitability and performance are accounting-based measures and market-based measures. ROA and ROE are usually employed as accounting-based measures, earnings per share and Tobin's $Q$ may be employed as market-based performance measures. Studies regarding corporate governance has increased rapidly after the launch of CGI. Karamustafa et al. [24] show that there is a significant difference in asset turnover, ROA and ROE of companies listed in CGI (in 2007) compare to prior years while Gürbüz et al. [8] conclude that companies listed on the Corporate Governance Index outperform those not listed in 2007. Except for years 2005 and 2006, non-corporate governance index companies are the better-performing companies. Sengur [25] compares the difference between performance measures of Corporate Governance Index Companies and Istanbul Stock Exchange-ISE 50 companies. The analysis shows that there is no significant difference in performance measures of companies in CGI and ISE 50 Companies. Likewise, the study revealed that there is no significant difference between performance measures of CGI Companies before and after being listed in CGI.

Financial risk on the other hand is usually measured by financial leverage but there is no consensus in the literature about the effect of this measure on corporate governance. According to agency cost view, Grossman and Hart [26] argue that debt financing provides better incentives for managers to perform as they aim to avoid the personal costs of bankruptcy. Another view suggests "high-quality" borrowers have incentives to show their quality [27]. Such high-quality borrowers want to show their performance by applying good corporate governance or debt holders may want to see sound corporate governance practices to protect their loan and return on risky investment. On the other hand, [28-30] indicate a negative relationship between corporate governance and financial leverage.

In addition to financial risk and profitability of the company, ownership structure also plays an important role in corporate governance mechanism, and it is often analyzed by focusing on ownership concentration and firm performance ([1,31-34]) and ownership identity $([3,23,35-37])$. Firms operating in poor investor protection environments usually have more concentrated ownership structure as argued by La Porta et al. [38] and Shleifer and Vishny [39]. This finding is only logical. In the absence of strong legal rights for small investors, minority investors want to keep enough number of 
shares to protect their rights. Thus, ownership concentration is seen by investors as a substitute for legal protection.

A common form of ownership concentration is via establishing family control over the company. In such family run businesses family members act as managers and are usually long-term oriented. Family-owners acting as managers for a long time also tend to develop comparative advantage through capital increases and searching for new investment opportunities compared to other nonfamily managers aiming for short-term profits. Thus, we can argue that long-term orientation of the family owner reduces agent cost [40] and lead to better performance outcomes [41]. There is also support to this view from the Turkish example. Ararat et al. [7] found a negative relationship between independent board members and firm performance. Their detailed research on the relationships between the independent board members and their firms suggests that a large fraction of these board members may not fulfill the requirements for independence and are not good monitors in the spirit of the corporate governance guidelines. Their interpretation for this result is the existence of possible links (personal, financial or social ties) between the dominant shareholders and the independent directors. This calls clearly for a revision of the corporate governance guidelines in Turkey. Agency problems may arise from the separation of ownership and management (Type I agency problem) or from conflicts of interest between controlling and non-controlling shareholders (Type II agency problem) ([42-45]). Both types of agency problems may lead managers to act against the best interests of shareholders.

Family-owner structure nevertheless has its disadvantages. In the case of weak shareholder protection, family owners have more opportunities to gain private control by expropriating minority shareholders' benefits $([46,47])$. This may adversely affect firm's performance. In most of the developing East Asian countries, wealth is very concentrated in the hands of few families and more than two-thirds of firms are controlled by a single shareholder [48]. This case is also valid for Turkey. $95 \%$ of the country's economy depends on family owned companies. As Gürsoy and Aydoğan [3] found that most of these family owned firms seem to have lower performance with lower risk while firms with foreign ownership display better performance. Pinto and Leal [49] showed that in another emerging market setting like Brazil, family controlled firms tend to pay more to their CEOs and board members when controlling shareholders or their relatives act as directors. Schiehll et al. [50] assert that family controlled firms in Brazil also tend not to voluntarily disclose their executive stock options plans.

Another aspect of ownership structure besides family control is foreign ownership. Studies usually point to a positive impact. As illustrated by Shleifer and Vishny [39], foreign equity investment results in better monitoring of company directors and as a result benefits all shareholders. By exercising their voting rights foreign investors can force out existing management and put in place more efficient directors.

The impact of foreign ownership on corporate governance depends however on the size of the ownership stake. If foreign investors control a sizeable stake in the company, they might also act in in their self-interest to exploit minority stake-holders. Known as the entrenchment hypothesis, this view suggests that more equity ownership by foreign industrial corporations that take part in active management of the company might worsen financial performance since the foreign stake-holder may not consider minority owners' interests [1,51]. Another view, known as the theory of private benefits of control [43], argues that the disincentive of foreign investors to improve corporate governance might be due to the fact that they receive potential private benefits with relative ease when corporate governance is weak. ${ }^{4}$

Testing whether either one of these theories hold in practice is an empirical project. There are studies that have looked at this relationship in developed market economies such as $[52,53]$ and we can

4 For more discussion on the topic, see [23] 
mention others who studied the linkage on emerging market settings such as [3,8,54], among others. ${ }^{5}$ Ananchotikul [23] has investigated this linkage in the case of Thailand and finds that the impact of foreign ownership on corporate governance is somewhat linked to the form of foreign investment. In the case of Thailand, foreign industrial investors do not necessarily improve corporate governance while purchases of minority stakes by foreign institutional investors lead to improvements. This is an interesting finding and shows to prove that the story around foreign ownership and corporate governance is not a clear-cut issue. Ananchotikul [23] also illustrates that the origin of foreign owner matters: there may be no improvements for firms who have a foreign owner that comes from a country with weak governance institutions.

Recently, there has been a proliferation of country-level evidence that the origin of legal rules and the quality of their enforcement in a country are good proxies for differences in investor protection which, in turn, affects the efficiency of its financial markets and its access to foreign capital (for example, see $[21,38,57,58])$. Firm-level empirical evidence has corroborated these findings: firms with better corporate governance practices have been found to have lower cost of capital ([41,59-61]), lower credit rate spreads [62], higher values, profitability, and lower risk ([16,18]), higher dividend payouts [63], and lower earnings management [64].

\section{Data and Methodology}

\subsection{Data}

Our data on corporate governance for Turkish companies comes from Borsa İstanbul bulletins, FINNET database and financial reports of firms announced on Public Disclosure Platform of Turkey. Although we started our calculation with 46 companies that currently have corporate governance ratings, we excluded firms operating in the financial services sector to prevent data distortion due to differences in firm operating characteristics. We also excluded some outlier observations. ${ }^{6}$ In the end, we reached 76 firm year observations with 22 firms covering a six-year time span from 2008 to 2012. ${ }^{7}$

In terms of ownership structure, Turkish corporations can be characterized as highly concentrated, family-owned firms attached to a group of companies generally owned by the same family or a group of families. The group usually includes a bank, which does not have significant equity ownership in member firms. Very large groups are well-diversified conglomerates sometimes with pyramidal structures. Others are usually vertically integrated companies in the same line of business. Although professional managers run these companies, family members are highly actively involved in strategic decision making and in daily activities [3].

Table 2 provides summary statistics on our dataset employed in this paper. ${ }^{8}$ We define foreign ownership as ownership in excess of $5 \%$ equity held by a foreign partner. ${ }^{9}$ In our sample, the

5 For Turkey, Gurbuz et al. [8] show evidence that institutional investors improve financial performance of Turkish firms. Akman et al. [54] find foreign ownership has a positive impact on firm performance consistent with [3]. Xu and Wang [55] and Claessens [56] also find evidence suggesting lower accounting-based performance, and higher market performances are experienced while the concentration in ownership increases in the cases of China, Slovak and Czech Republics. On the contrary, [20] find no systematic relation between ownership structure and firm performance.

6 Observations that were more than six standard deviations away from category means are excluded. In total, five year-firm observations are dropped.

7 Financial institutions including banks and participation banks, insurance companies, financial leasing and factoring companies, holding and investment companies, investment trusts, real estate investment trusts, venture capital investment trusts and brokerage houses are excluded.

8 Most of the Turkish firms have a complex network of ownership; i.e., Hurriyet operates in manufacturing of paper and paper products as well as in printing and publishing sector. Doğan Yayın Holding owns 66\% of the company and Doğan Holding owns another 11\% stake in the company. Doğan Yayın Holding is owned by Doğan Holding and Doğan Holding is owned by Doğan family. Keeping Doğan Holding and Hurriyet in the sample may cause duplication of data. Thus, holdings in such situations are excluded.

9 Foreign ownership can be as portfolio investment or direct investment. Joint venture is not common in Turkish Capital Market. 
average is $14.46 \%$. Maximum family ownership stake is $77.5 \%$ with a mean of $47.92 \%$. In the sample, government ownership exists for only two companies. ${ }^{10}$

Table 2. Descriptive Statistics.

\begin{tabular}{ccccccc}
\hline Variable & Mean & Min. & Max. & Std. Dev. & No. Of Obs. & Skewness \\
\hline CGR & 84.488 & 71.2 & 92.44 & 4.144 & 76 & -0.577 \\
EPS & 0.952 & -0.42 & 5.85 & 1.271 & 76 & 2.240 \\
ROE & 15.564 & -38.55 & 52.16 & 14.730 & 76 & -0.409 \\
FL & 51.599 & 2.42 & 84.99 & 20.029 & 76 & -0.754 \\
OPG & 27.177 & -116.66 & 347.98 & 83.412 & 76 & 1.860 \\
TA & $3,866,663$ & 37,300 & $17,208,000$ & $4,639,135$ & 76 & 1.526 \\
\hline
\end{tabular}

The table shows descriptive statistics for our dataset. EPS stands for earnings per share in Turkish Liras; CGR stands for the corporate governance index score assigned by the rater; ROE is return on equity measured as percentage points; ROA is return on assets measured as percentage points; FL stands for financial leverage calculated as the ratio of liabilities to equity; OPG represents growth of Operating Profit in percentage points; FOREIGN is a percentage of foreign ownership; FAMILY represents the dummy variable that takes the value of 1 if the company is controlled by a family; and TA is the total assets of the company in thousands of Turkish liras.

\subsection{Empirical Specification}

We follow [23] in setting up our empirical estimation in evaluating the link between foreign ownership and corporate governance in the case of Turkey. Our empirical estimation takes the following form:

$$
C G R_{i, t}=\beta_{0}+\sum_{k=1}^{k} \gamma_{k} \operatorname{CONTROL}_{i, t-1}^{k}+\beta_{1} \text { FAMILY }_{i, t-1}+\beta_{2} \text { FOREIGN }_{i, t-1}+\varepsilon_{i, t}
$$

where $\mathrm{CGR}_{i, t}$ represents the corporate governance rating for firm $i$ at time $t$; FAMILY Fit-1 $_{1}$ is a dummy variable that represents controlling stake in company $i$ by a family at time $t-1$. As mentioned before Turkish companies can be characterized as highly concentrated, family owned firms attached to a group of companies generally owned by the same family or a group of families in the form of holding. If the family members have significant voting rights associated with their sizeable stake, the dummy takes the value of 1 and otherwise 0 . "Significant voting rights" refer to $50 \%$ or higher stake in the company held by family members or their representatives. If family members or their representatives account for the majority of the board or have equity over $50 \%$ of the company, we assign a value of 1 for this variable, and 0 otherwise. This information is collected by analyzing board structures of companies and disclosure notes in financial reports. CGR reports usually include a section regarding the evaluation of the composition of the board of directors, but the classification of family management is determined by reading the annual financial reports, disclosures and by collecting data about family members. FOREIGN ${ }_{i, t-1}$ represents foreign ownership dummy that takes the value of 1 if the firm $i$ at time $t-1$ has foreign equity partners and 0 otherwise. CONTROL $L_{i, t-1}^{k}$ is a matrix of control variables for firm $i$ and includes the following:

- Firm's profitability measured by the following accounting and market-based ratios:

- Earnings per share $\left(\mathrm{EPS}_{i, t-1}\right)$ in Turkish liras is calculated by dividing net income to the average number of outstanding shares in the previous reporting period.

- Return on equity $\left(\mathrm{ROE}_{i, t-1}\right)$ is calculated as the ratio of previous fiscal year's net income to previous year's average total equity.

10 Turkish State has shares in Turk Telekom, a telecommunications company and Aselsan, a defense contractor. 
- Growth of company's operating profit $\left(\mathrm{OPG}_{i, t-1}\right)$ is calculated as the change in operating profit divided into prior year's net operating profit. ${ }^{11}$

- Financial Risk measured by financial leverage ratio $\left(\mathrm{FL}_{i, t-1}\right)$ calculated as the ratio of company's total debt (sum of short term and long term liabilities) to total liabilities and owners' equity in the previous year.

- Firm's size measured by the log of company's total assets $\left(\mathrm{TA}_{i, t-1}\right)$.

We take a one-period lag of all control variables in our specification since most CGR reporting companies rely on previous period's reports in calculating governance ratings. We expect a company's CGR reading to be influenced by its risk and profitability. The rationale is higher profits could be a sign of excessive risk taking, which should lower a firm's CGR reading, or vice versa. In the meantime, excessive risk can be identified by the firm's financial leverage ratio, which can have an adverse effect on the company's CGR reading. Table 3 provides correlation between our variables and expected signs for the variables used in the estimation of Equation (1) can be found in Table 4.

Table 3. Correlation Matrix.

\begin{tabular}{|c|c|c|c|c|c|c|c|c|c|}
\hline & $\mathrm{CGR}_{i, t}$ & $\mathrm{CGR}_{i, t-1}$ & EPS $_{i, t-1}$ & $\operatorname{ROE}_{i, t-1}$ & $\mathrm{FL}_{i, t-1}$ & $\mathrm{OPG}_{i, t-1}$ & FAMILY $_{i, t-1}$ & FOREIGN $_{i, t-1}$ & $\mathbf{T A}_{i, t-1}$ \\
\hline $\mathrm{CGR}_{i, t}$ & 1.00 & 0.86 & 0.23 & 0.18 & 0.18 & 0.13 & -0.01 & -0.06 & 0.40 \\
\hline $\mathrm{CGR}_{i, t-1}$ & 0.86 & 1.00 & 0.17 & 0.15 & 0.15 & 0.14 & 0.01 & -0.05 & 0.35 \\
\hline $\operatorname{ROE}_{i, t-1}$ & 0.18 & 0.15 & 0.67 & 1.00 & 0.19 & 0.35 & -0.18 & 0.41 & 0.44 \\
\hline $\mathrm{FL}_{i, t-1}$ & 0.18 & 0.15 & 0.20 & 0.19 & 1.00 & 0.05 & -0.08 & 0.22 & 0.52 \\
\hline $\mathrm{OPG}_{i, t-1}$ & 0.13 & 0.14 & 0.26 & 0.35 & 0.05 & 1.00 & -0.03 & 0.01 & -0.05 \\
\hline $\mathbf{T A}_{i, t-1}$ & 0.40 & 0.35 & 0.32 & 0.44 & 0.52 & -0.05 & 0.13 & 0.33 & 1.00 \\
\hline
\end{tabular}

The table shows the correlation matrix for the variables used in our analysis. CGR is the Corporate Governance rating for each company in our dataset; EPS stands for earnings per share in Turkish Liras; ROE is return on equity measured as percentage points; ROA is return on assets measured as percentage points; FL stands for financial leverage calculated as the ratio of liabilities to equity; OPG represents growth of Operating Profit in percentage points; FAMILY is a dummy variable that takes the value of 1 if the company is controlled by a family; FOREIGN is a dummy variable that takes the value of 1 if the company has foreign ownership and 0 otherwise; and TA represents log of company's total assets.

Table 4. Estimation Variables and Expected Signs.

\begin{tabular}{cccc}
\hline & Variable & Abbreviation & Expected Sign of the Coefficient \\
\hline \multirow{2}{*}{ Profitability Measures } & Earnings Per Share (in TL) & EPS & + \\
\multirow{2}{*}{ Risk Measures } & Return on Equity & ROE & $+/-$ \\
& Growth of Operating Profit & OPG & + \\
Ownership Structure Variables & Financial Leverage & FL & $+/-$ \\
& Foreign ownership & FOREIGN & $?$ \\
& Family Ownership & FAMILY & $?$ \\
\hline
\end{tabular}

The table shows the estimated signs of the variables used in our estimations. TL: Turkish lira. " + " refers to a positive sign, while "-" refers to a negative sign of the coefficient. "?" means the expected sign is undetermined.

\section{Estimation Results}

This section provides the results of our estimations for Equation (1). We perform a two-level procedure in our analysis. First we run stepwise static OLS estimations. Before doing so, we perform Hausman Test to check for the validity of the fixed effects model. The $\chi^{2}$ value with 21 degrees of freedom is 121.63 with a $p$ value that is equal to 0 . The $p$-value strongly rejects the null hypothesis

11 In year-end financial reports of companies in Turkey, other operating income and other operating expense are also taken into account in profit calculations. For an accurate calculation and to indicate performance only about a firm's operating area we excluded other operating income and expense in our calculations of this variable. 
that cross-section effects are redundant supporting the use of fixed effects model. In order to account for possible persistence in CGR readings, we slightly modify Equation (1) and include a lag of our endogenous variable $\left(\mathrm{CGR}_{t-1}\right)$. The reason we use a lag of our dependent variable on the right hand side is because CGR readings are usually influenced by the previous period's reading, a finding shown with a high correlation between the two variables. ${ }^{12}$ Previous literature has shown that firm structure measures are highly endogenous to CGR estimations. ${ }^{13}$ The solution to endogeneity works if we can find instrumental variables that are correlated with the endogenous regressor. When assuming the ownership structure to be endogenous, [65-67] use generalized method of moments with a panel of data to remove the simultaneous effect of performance on ownership structure and to increase the adequacy of the empirical test. Thus, for the modified versions of Equation (1), we use the dynamic Generalized Method of Moments (GMM) following the strategy of Arellano and Bond [68]. We use all possible lags of our dependent variable plus lagged values of our ownership structure (FAMILY) and company size (TA) variables as instruments. By doing so we obtain parameter estimates that are consistent and efficient. We have 18 firms that we can use in our dynamic panel GMM model; this increases our confidence in the consistency and efficiency of our estimates.

The results of our estimations are available in Table 5. Specifications (1.1) through (1.7) show the stepwise estimations using Equation (1). Specifications (2.1) and (2.2) show the GMM specification for Equation (1). We observe that across all the specifications, earnings per share in the previous period $\left(\mathrm{EPS}_{i, t-1}\right)$ have a robust effect on the CGR ratings. This suggests that firms with higher earnings also receive higher corporate governance readings. This finding confirms our expectations regarding the impact of firm's profitability on its corporate governance rating. Another variable that has a robust effect on corporate governance ratings is a company's size. In specifications (1.7) and (2.2), this variable has a positive sign and is highly significant. This suggests company's size greatly influences its corporate governance rating. Thus in the case of Turkey, bigger firms receive higher corporate governance ratings. Financial leverage in the previous period $\left(\mathrm{FL}_{i, t-1}\right)$ measured by the ratio of firm's liabilities to its equity is also another significant and robust variable. The positive sign of this variable suggests as firms' liabilities increase relative to their equity their corporate governance rating also increases. We can explain this result as follows: faster growing firms need external capital to sustain growth, and therefore might choose better governance to attract investors. The positive and significant sign of FL in our models is an indicator that high-quality borrowers want to show their performance by applying good corporate governance practices. Additionally, we can argue that a contributing factor is the scrutiny the firm is subject to as its liability portfolio increases. A significant portion of liabilities for a firm is loans; higher loans bring along with more scrutiny towards a firm's finances and operations by the creditors. This may result in highly leveraged firms to behave more conservatively and compliant thus receiving higher CGR scores. This finding is in line with previous research such as [27], which has demonstrated that debt holders may want to see sound corporate governance practices to secure their repayment.

12 The coefficient of correlation between $C G R_{t}$ and $C G R_{t-1}$ is 0.86 .

13 See $[13,23]$. 
Table 5. Estimation Results.

\begin{tabular}{|c|c|c|c|c|c|c|c|c|c|}
\hline Dependent Variable: $C_{G} R_{i t}$ & (1.1) & (1.2) & (1.3) & (1.4) & (1.5) & (1.6) & (1.7) & $(2.1)$ & $(2.2)$ \\
\hline Method & OLS & OLS & OLS & OLS & OLS & OLS & OLS & GMM & GMM \\
\hline Time Period & 2008-2012 & 2008-2012 & 2008-2012 & 2008-2012 & 2008-2012 & 2008-2012 & $2008-2012$ & 2010-2013 & 2010-2013 \\
\hline $\mathrm{C}$ & $\begin{array}{c}84.61^{* * *} \\
(0.57)\end{array}$ & $\begin{array}{c}84.79 * * * \\
(0.68)\end{array}$ & $\begin{array}{c}78.59 * * * \\
(3.56)\end{array}$ & $\begin{array}{c}78.92 * * * \\
(3.59)\end{array}$ & $\begin{array}{c}80.09 * * * \\
(3.71)\end{array}$ & $\begin{array}{c}79.80^{* * *} \\
(3.67)\end{array}$ & $\begin{array}{c}-82.60 * * * \\
(25.60)\end{array}$ & & \\
\hline $\mathrm{CGR}_{i, t-1}$ & & & & & & & & $\begin{array}{c}0.70^{* * *} \\
(0.09)\end{array}$ & $\begin{array}{c}0.65^{* * *} \\
(0.08)\end{array}$ \\
\hline $\mathrm{EPS}_{i, t-1}$ & $\begin{array}{c}2.41^{* * *} \\
(0.48)\end{array}$ & $\begin{array}{c}2.61^{* * *} \\
(0.64)\end{array}$ & $\begin{array}{c}2.68^{* * * *} \\
(0.62)\end{array}$ & $\begin{array}{c}2.83^{* * *} \\
(0.64)\end{array}$ & $\begin{array}{c}2.80^{* * *} \\
(0.64)\end{array}$ & $\begin{array}{c}2.81^{* * *} \\
(0.63)\end{array}$ & $\begin{array}{l}1.05^{*} \\
(0.54)\end{array}$ & $\begin{array}{c}1.91 * * * \\
(0.62)\end{array}$ & $\begin{array}{c}2.53 \text { *** } \\
(0.96)\end{array}$ \\
\hline $\mathrm{ROE}_{i, t-1}$ & & $\begin{array}{l}-0.02 \\
(0.05)\end{array}$ & $\begin{array}{l}-0.02 \\
(0.04)\end{array}$ & $\begin{array}{l}-0.05 \\
(0.06)\end{array}$ & $\begin{array}{l}-0.05 \\
(0.06)\end{array}$ & $\begin{array}{l}-0.06 \\
(0.06)\end{array}$ & $\begin{array}{l}-0.06 \\
(0.04)\end{array}$ & $\begin{array}{c}-0.07^{* *} \\
(0.04)\end{array}$ & $\begin{array}{c}-0.16^{* *} \\
(0.04)\end{array}$ \\
\hline $\mathrm{FL}_{i, t-1}$ & & & $\begin{array}{l}0.12^{*} \\
(0.06)\end{array}$ & $\begin{array}{l}0.11^{*} \\
(0.07)\end{array}$ & $\begin{array}{l}0.12 * \\
(0.07)\end{array}$ & $\begin{array}{l}0.11^{*} \\
(0.07)\end{array}$ & $\begin{array}{l}-0.03 \\
(0.05)\end{array}$ & $\begin{array}{c}0.11^{* * *} \\
(0.04)\end{array}$ & $\begin{array}{c}0.12^{* * *} \\
(0.04)\end{array}$ \\
\hline $\mathrm{OPG}_{i, t-1}$ & & & & $\begin{array}{c}0.005 \\
(0.005)\end{array}$ & $\begin{array}{c}0.005 \\
(0.005)\end{array}$ & $\begin{array}{c}0.005 \\
(0.005)\end{array}$ & $\begin{array}{c}0.005 \\
(0.004)\end{array}$ & $\begin{array}{c}0.003 \\
(0.003)\end{array}$ & $\begin{array}{c}0.004 \\
(0.005)\end{array}$ \\
\hline FAMILY $_{i, t-1}$ & & & & & $\begin{array}{l}-2.35 \\
(2.01)\end{array}$ & $\begin{array}{c}-4.78^{*} \\
(2.53)\end{array}$ & $\begin{array}{l}-0.85 \\
(1.97)\end{array}$ & $\begin{array}{l}-2.42 \\
(2.53)\end{array}$ & $\begin{array}{c}1.82 \\
(4.03)\end{array}$ \\
\hline FOREIGN $_{i, t-1}$ & & & & & & $\begin{array}{c}6.43 \\
(4.16)\end{array}$ & $\begin{array}{c}12.90^{* * * *} \\
(3.24)\end{array}$ & $\begin{array}{c}4.47 \\
(5.15)\end{array}$ & $\begin{array}{l}-0.3 \\
(6.29)\end{array}$ \\
\hline$T A_{i, t-1}$ & & & & & & & $\begin{array}{c}11.57^{* * * *} \\
(1.81)\end{array}$ & & $\begin{array}{l}3.26^{* *} \\
(1.57)\end{array}$ \\
\hline Adj. $R^{2}$ & 0.51 & 0.51 & 0.52 & 0.52 & 0.53 & 0.54 & 0.74 & & \\
\hline No. of firms & 22 & 22 & 22 & 22 & 22 & 22 & 22 & 18 & 18 \\
\hline No. of observations & 76 & 76 & 76 & 76 & 76 & 76 & 76 & 54 & 54 \\
\hline S.E. of Regression & & & & & & & & 2.16 & 2.50 \\
\hline $\mathrm{AR}(1)$ & & & & & & & & $\begin{array}{c}\mathrm{Z}=-0.154 \\
p=0.33\end{array}$ & $\begin{array}{c}\mathrm{Z}=-0.145 \\
p=0.36\end{array}$ \\
\hline $\mathrm{AR}(2)$ & & & & & & & & $\begin{array}{c}\mathrm{Z}=-0.024 \\
p=0.61\end{array}$ & $\begin{array}{c}\mathrm{Z}=-0.037 \\
p=0.63\end{array}$ \\
\hline
\end{tabular}


Table 5. Cont

\begin{tabular}{|c|c|c|c|c|c|c|c|c|c|}
\hline Dependent Variable: CGR $_{\text {it }}$ & (1.1) & (1.2) & (1.3) & (1.4) & (1.5) & (1.6) & (1.7) & (2.1) & (2.2) \\
\hline Sargan Test $p$ value & & & & & & & & 0.49 & 0.42 \\
\hline Instruments used & & & & & & & & CGR, FAMILY, TA & CGR, FAMILY, TA \\
\hline
\end{tabular}

The table shows the results of stepwise estimations for Equation (1) using OLS and GMM techniques. All OLS estimations include fixed effects that are not reported here. The results are T-stat coefficients, and Standard errors reported are in brackets. EPS stands for earnings per share in Turkish Liras; FITCH is a dummy variable that takes the value of 1 following the upgrade of Turkey's credit rating to investment-grade status in 2012; ROE is return on equity measured as percentage points; ROA is return on assets measured as percentage points; FL stands for financial leverage calculated as the ratio of liabilities to total liabilities and owners' equity; OPG represents growth of Operating Profit in percentage points; FAMILY is a dummy variable that takes the value of 1 if the company is controlled by a family; FOREIGN is a foreign ownership dummy that takes the value of 1 if the corporation has foreign ownership and 0 otherwise; and TA represents $\log$ of company's total assets. * represents significance at $10 \%,{ }^{* *}$ represents significance at $5 \%$ and ${ }^{* * *}$ represents significance at $1 \%$. The null hypothesis for the Sargan Test is the instrumental variables are uncorrelated to some set of residuals. The null hypothesis for AR (k) test is there is no autocorrelation up to order $\mathrm{k}$. 
Of the two ownership structures that we are particularly interested in the family ownership dummy (FAMILY ${ }_{i, t-1}$ ) takes on a negative coefficient and is significant in only one of the five specifications we present. The interpretation is that rating companies may read controlling stakes by a family in a firm's ownership structure as unfavorable conditions in assessing their corporate governance ratings. However, this relationship is not robust in all estimations. The foreign ownership dummy, on the other hand (FOREIGN ${ }_{i, t-1}$ ), is insignificant in most of our estimations except when company size is controlled.

Another important finding in our results is the effect of previous period's CGR reading. The high significance of this variable in GMM estimations suggests that raters take into consideration previous period's CGR levels in assigning new CGR scores to firms.

We also observe that profitability is closely linked to CGR scores as illustrated by the GMM estimations. Corporations' return on equity in the previous financial period $\left(\mathrm{ROE}_{i, t-1}\right)$ enters our estimations with a negative sign suggesting that higher returns on equity yield lower CGR readings. This finding is consistent with the private control benefit argument made by [46]: the divergence of voting rights and cash flow rights allows the block holder to gain private benefit because it has high control power and low capital involvement.

The growth of operating profit (OPG) is significant in all of our specifications suggesting no impact on a company's corporate governance rating.

\section{Conclusions}

Ownership structure, as a mechanism in corporate governance has been believed to effect firm performance for many years. The relationship between ownership structure and corporate performance are assumed to exist because ownership concentration and owner identity influence the incentives of each party within the firm, and thus influence the firm's ability to solve agency problems. The conflict of shareholders and management is expected to decrease with good corporate governance practices. It is also becoming more common for investors to consider governance issues when making investment decisions. In response to such interest, several organizations now rate the corporate governance practices of public companies, either as a stand-alone offering or as part of a credit rating. In line with international practices, Turkey's CMB established the [69] and since 2007 Borsa Istanbul has been listing a Corporate Governance Index for Turkish companies. This index was created to expand the breadth and significance of corporate governance applications and to promote the voluntary compliance. Turkish firms generally respond to the mandatory disclosure regulations but do not address governance issues and environmental and social areas adequately where standards are not mandatory [70]. The index gives firms an opportunity to differentiate themselves. In this paper we evaluated the impact of ownership structure on Turkish firm's CGRs. In doing so, we compiled data on 22 publicly traded Turkish companies and their ownership structures. Our estimations suggest that earnings, company size and financial leverage have a positive impact of a Turkish firm's corporate governance rating. In the meantime, return on equity negatively impacts a firm's CGR rating. We find some evidence that family control has a significant and negative impact on Turkish firms' CGR scores, suggesting that controlling stakes by a family are considered as unfavorable conditions from a corporate governance perspective in the case of Turkey and thus such firms receive lower CGR scores. Although CGR scores may not truly represent governance quality in a firm, this finding has important policy implications for Turkey where the corporate landscape is characterized by such family owned conglomerates. In that regard, weakening of family control on Turkish corporations seems to be an important step in improving corporate governance in Turkey. However, this finding is not robust in all of our estimations and therefore should not be regarded as conclusive. The same can be said regarding the impact of foreign ownership on corporate governance ratings in Turkey. Although we have some evidence that suggests firms with foreign ownership receive higher CGR readings in Turkey, this is not a robust finding and needs further exploration. 
Another implication of our results is the relationship between financial risk and corporate governance ratings in the case of Turkey. We measured financial risk by financial leverage (FL) in our estimations. This variable has a robust positive impact on Turkish firms' CGR scores. Faster growing firms with high debt seem to receive higher corporate governance ratings in the Turkish case. Alternatively, firms that want to attract capital may implement governance measures that result in higher CG ratings.

Our study has valuable contribution to literature on corporate governance in emerging market settings in the case of Turkey and is expected to be of interest to regulators, researchers, managers and market participants. This paper can also be seen as an application of the type II agency problem to Turkey. As of 2015, only a few emerging market economies have corporate governance indices and only three are applying voluntary application. Further research may focus on cross-sectional analysis of ownership structure and especially on family control of corporate boards in other emerging market cases and determinants of the decision for CG ratings to see whether our results hold.

Acknowledgments: We gratefully acknowledge helpful comments and suggestions from Kenth Skogsvik, Martin Walker, Florian Eugster, Henrik Nilsson and the participants in the Stockholm School of Economics Seminar in September 2014. We are grateful for the research help received from Dean Akdis of Gediz University.

Author Contributions: Abidin Ates and Sevin Gurarda contributed to data collection; Sevin Gurarda and Emre Ozsoz conceived and designed the estimation specification; Sevin Gurarda and Emre Ozsoz analyzed the data; and Abidin Ates, Sevin Gurarda and Emre Ozsoz jointly wrote the paper.

Conflicts of Interest: The authors declare no conflict of interest.

\section{References}

1. Shleifer, A.; Vishny, R.W. A survey of Corporate Governance. J. Finance 1997, 52, 737-783. [CrossRef]

2. Doidge, C.; Karolyi, G.A.; Stulz, R. Why do countries matter so much for corporate governance? J. Financ. Econ. 2007, 86, 1-39. [CrossRef]

3. Gursoy, G.; Aydogan, K. Equity Ownership, Risk Taking and Performance: An Empirical Investigation in Turkish Listed Companies. Emerg. Mark. Financ. Trade 2002, 38, 6-25.

4. Demirag, I.; Serter, M. Ownership Patterns and Control in Turkish Listed Companies. Corp. Gov.: Int. Rev. 2003, 11, 40-51. [CrossRef]

5. Yıldırım, Ö.; Üsdiken, B. Contingencies versus external pressure: Board composition in firms affiliated to diversified family business groups in late-industrializing countries. Br. J. Manag. 2010, 21, 115-130. [CrossRef]

6. Ararat, M.; Süel, E.; Yurtoğlu, B.B. Sustainable Investment in Turkey: The Case in Context-An Update; Sabanc1 University: İstanbul, Turkey, 2014.

7. Ararat, M.; Orbay, H.; Yurtoglu, B. The Effects of Board Independence in Controlled Firms: Evidence from Turkey. Working Paper. 2010. Available online: http://papers.ssrn.com/sol3/papers.cfm?abstract_id= 1663403 (accessed on 15 August 2015).

8. Gürbüz, A.O.; Aybars, A.; Kutlu, Ö. Corporate Governance and Financial Performance with a Perspective on Institutional Ownership: Empirical Evidence from Turkey. J. Appl. Manag. Account. Res. 2010, 8, 21-37.

9. Ugur, M.; Ararat, M. Does Macroeconomic Performance Affect Corporate Governance? Evidence from Turkey. Corp. Gov.: Int. Rev. 2006, 14, 325-348. [CrossRef]

10. Grimminger, A.D.; Di Benedetta, P. Raising the Bar on Corporate Governance: A Study of Eight Stock Exchange Indices; World Bank and the International Financial Corporation: Washington, DC, USA, 2013.

11. Ananchotikul, S.; Eichengreen, B. Corporate governance reform in emerging markets: How much, why, and with what effects? J. Jpn. Int. Econ. 2009, 23, 149-176. [CrossRef]

12. Brown, L.D.; Caylor, M.L. Corporate Governance and Firm Operating Performance. Rev. Quant. Financ. Account. 2009, 32, 129-144. [CrossRef]

13. Larcker, D.F.; Richardson, S.A.; Tuna, I. Corporate Governance, Accounting Outcomes, and Organizational Performance. Account. Rev. 2007, 6, 963-1008. [CrossRef]

14. Abdullah, A.; Page, M. Corporate Governance and Corporate Performance: UK FTSE 350 Companies; The Institute of Chartered Accountants of Scotland: Edinburgh, UK, 2009. 
15. Sami, H.; Wang, J.; Zhou, H. Corporate governance and operating performance of Chinese listed firms. J. Int. Account. Audit. Tax. 2011, 20, 106-114. [CrossRef]

16. Brown, L.D.; Caylor, M.L. Corporate governance and firm performance. Account. Rev. 2005, 80, 423-440. [CrossRef]

17. Mashayekhi, B.; Bazaz, M.S. Corporate Governance and Firm Performance in Iran. Unpublished Master's Thesis, University of Tehran and Oakland University, Tehran, Iran, 2008.

18. Gompers, P.; Ishii, J.; Metrick, A. Corporate Governance and Equity Prices. Q. J. Econ. 2003, 118, $107-155$. [CrossRef]

19. Wu, S.; Cui, H. Consequences of The Concentrated Ownership Structure in Mainland China_Evidence of Year 2000; Working paper; City University of Hong Kong: Hong Kong, China, 2002.

20. Demsetz, H.; Villalonga, B. Ownership Structure and Corporate Performance. J. Corp. Finance 2001, 7, 209-233. [CrossRef]

21. Gugler, K.; Mueller, D.C.; Yurtoglu, B.B. Corporate Governance and the Return on Investment. J. Law Econ. 2004, 47, 589-633. [CrossRef]

22. Core, J.; Guay, W.; Rusticus, T. Does Weak Governance Cause Weak Stock Returns? An Examination of Firm Performance and Analysts' Expectation; Working Paper; University of Pennsylvania: Philadelphia, PA, USA, 2005.

23. Ananchotikul, N. Does Foreign Direct Investment Really Improve Corporate Governance? Evidence from Thailand; Discussion Paper; Bank of Thailand: Bangkok, Thailand, 2008.

24. Karamustafa, O.; Varıcı, İ.; Er, B. Kurumsal Yönetim ve Firma Performansı: İMKB Kurumsal Yönetim Endeksi Kapsamındaki Firmalar Üzerinde Bir Uygulama. Kocaeli Univ. Sos. Bilim. Enst. Derg. 2009, 17, 100-119.

25. Sengur, E.D. Do Corporate Governance Index Companies Outperform Others?: Evidence from Turkey. Int. J. Bus. Soc. Sci. 2011, 2, 254-260.

26. Grossman, S.J.; Hart, O. Corporate financial structure and managerial incentive. In The Economics of Information and Uncertainty; McCall, J., Ed.; University of Chicago Press: Chicago, IL, USA, 1982.

27. Stiglitz, J.; Weiss, A. Credit Rationing in Markets with Imperfect Information. Am. Econ. Rev. 2007, 71, 393-410.

28. Pushner, G.M. Equity ownership structure, leverage, and productivity: Empirical evidence from Japan. Pac.-Basin Finance J. 1995, 3, 241-255. [CrossRef]

29. Nickell, S.; Nicolitsas, D.; Dryden, N. What makes firms perform well? Eur. Econ. Rev. 2007, 41, $783-796$. [CrossRef]

30. Arping, S.; Sautner, Z. Corporate governance and leverage: Evidence from a natural experiment. Finance Res. Lett. 2010, 7, 127-134. [CrossRef]

31. Larner, R.J. Ownership and control in the 200 largest nonfinancial corporations, 1929 and 1963. Am. Econ. Rev. 1966, 56, 777-787.

32. Short, H. Ownership, Control, Financial Structure and the Performance of Firms. J. Econ. Surv. 1994, 8, 203. [CrossRef]

33. Holderness, C.G.G. A Survey of Blockholders and Corporate Control. Econ. Policy Rev. 2003, 9, 51-63. [CrossRef]

34. Denis, D.J.; Serrano, J.M. Active investors and management turnover following unsuccessful control contests. J. Financ. Econ. 1996, 40, 239-266. [CrossRef]

35. Mehran, H. Executive Compensation Structure, Ownership and Firm Performance. J. Financ. Econ. 1995, 38, 163-184. [CrossRef]

36. Huizinga, H.; Denis, C. Are Foreign Ownership and Good Institutions Substitutes? The European Evidence; European Commission: Brussels, Belgium, 2003.

37. Hartzell, J.C.; Starks, L.T. Institutional Investors and Executive Compensation. J. Finance 2003, 5S, $2351-2374$. [CrossRef]

38. La Porta, R.; Silanes, F.L.; Shleifer, A.; Vishny, R.W. Law and Finance; Working Paper; National Bureau of Economic Research: Cambridge, MA, USA, 1996.

39. Shleifer, A.; Vishny, R.W. Large Shareholders and Corporate Control. J. Political Econ. 2007, 94, 461-488. [CrossRef]

40. Hsu, C.Y.; Chen, Y.L.; Lin, W.Y. Corporate governance and credit risk. NTU Manag. Rev. 2007, 6, 100-110. 
41. Mazumdar, S.C.; Sarin, A.; Sengupta, P. To Tell or Not to Tell: The Value of Corporate Disclosure; Working paper; Santa Clara University: Santa Clara, CA, USA, 2002.

42. Charitou, A.; Louca, C.; Tsalavoutas, I. Corporate Governance, Agency Problems, and Firm Performance: Empirical Evidence from an Emerging European Market. Working Paper. 2014. Available online: http:/ / papers.ssrn.com/sol3/papers.cfm?abstract_id=2221612 (accessed on 14 April 2016).

43. Bebchuk, L.; Kraakman, R.; Triantis, G. Stock Pyramids, Cross-Ownership, and Dual Class Equity: The Creation and Agency Costs of Separating Control from Cash Flow Rights; Discussion Paper; National Bureau of Economic Research: Cambridge, MA, USA, 1999.

44. La Porta, R.; Silanes, F.L.; Shleifer, A. Corporate ownership around the World. J. Finance 1999, 54, 471-517. [CrossRef]

45. Eklund, J.; Palmberg, J.; Wiberg, D. Inherited corporate control and returns on investment. Small Bus. Econ. 2013, 41, 419-431. [CrossRef]

46. Chen, J. Special Issue: Corporate finance and corporate governance in contemporary China. J. Chin. Econ. Bus. Stud. 2012, 2, 109-207. [CrossRef]

47. Villalonga, B.; Amit, R. How do family ownership, control and management affect firm value? J. Financ. Econ. 2006, 80, 385-417. [CrossRef]

48. Claessens, S.; Djankov, S.; Lang, L.H.P. The separation of ownership and control in East Asian Corporations. J. Financ. Econ. 2000, 58, 81-112. [CrossRef]

49. Pinto, M.B.; Leal, R.P.C. Ownership concentration, top management and board compensation. Rev. Adm. Contemp. 2013, 17, 304-324. [CrossRef]

50. Schiehll, E.; Terra, P.R.; Victor, F.G. Determinants of voluntary executive stock option disclosure in Brazil. J. Manag. Gov. 2013, 17, 331-361. [CrossRef]

51. Morck, R.; Shleifer, A.; Vishny, R.W. Management ownership and market valuation: An empirical analysis. J. Financ. Econ. 1988, 20, 293-315. [CrossRef]

52. Doidge, C.; Karolyi, G.A.; Stulz, R. Why are foreign firms listed in the US worth more? J. Financ. Econ. 2004, 71, 205-238. [CrossRef]

53. Ammann, M.; Oesch, D.; Schmid, M. Corporate governance and firm value: International evidence. J. Empir. Finance 2011, 18, 36-55. [CrossRef]

54. Akman, N.H.; Mugan, C.S.; Akisik, O. Ownership structure effect on firm performance: Evidence from an emerging market. In Proceedings of the 8th International Accounting Conference Corporate Governance and Control, Izmir University of Economics Conference Hall, Izmir, Turkey, 20-22 October 2011.

55. Xu, X.; Wang, Y. Ownership Structure, Corporate Governance, and Corporate Performance: The Case of Chinese Stock Companies; Working Paper; World Bank: Washington, DC, USA, 1997.

56. Claessens, S. Corporate Governance and Equity Prices: Evidence from the Czech and Slovak Republics. J. Finance 1997, 52, 1641-1658. [CrossRef]

57. La Porta, R.; Silanes, F.L.; Shleifer, A.; Vishny, R.W. Legal Determinants of External Finance. J. Finance 1997, 52, 1131-1150. [CrossRef]

58. Shleifer, A.; Wolfenzon, D. Investor protection and equity markets. J. Financ. Econ. 2002, 66, 3-27. [CrossRef]

59. Sengupta, P. Corporate Disclosure Quality and the Cost of Debt. Account. Rev. 1998, 73, 459-474.

60. Ashbaugh, H.; Collins, D.W.; LaFond, R. Corporate Governance and the Cost of Equity Capital. Working Paper. 2004. Available online: http://papers.ssrn.com/sol3/papers.cfm?abstract_id=639681 (accessed on 15 August 2015).

61. Frantz, P.; Instefjord, N.; Walker, M. Executive Compensation: A Model of Disclosure Choice. J. Bus. Financ. Account. 2013, 40, 1184-1220. [CrossRef]

62. Yu, F. Accounting Transparency and the Term Structure of Credit Spreads. J. Financ. Econ. 2005, 75, 53-84. [CrossRef]

63. Adjaoud, F.; Ben Amar, W. Corporate Governance and Dividend Policy: Shareholders' Protection or Expropriation? J. Bus. Financ. Account. 2010, 37, 648-667. [CrossRef]

64. Cormier, D.; Pascale, L.; Bruce, J.M. Forecasts in IPO Prospectuses: The Effect of Corporate Governance on Earnings Management. J. Bus. Financ. Accoun. 2014, 41, 100-127. [CrossRef]

65. Demsetz, H.; Lehn, K. The Structure of Corporate Ownership: Causes and Consequences. J. Political Econ. 1985, 93, 1155-1177. [CrossRef] 
66. Cho, M.H. Ownership structure, investment, and corporate value: An empirical analysis. J. Financ. Econ. 1998, 47, 103-121. [CrossRef]

67. Hermalin, B.; Michael, W. The Determinants of board composition. Rand J. Econ. 1989, 19, 589-606. [CrossRef]

68. Arellano, M.; Bond, S. Some tests of specification for panel data: Monte Carlo evidence and an application to employment equations. Rev. Econ. Stud. 1991, 58, 277-297. [CrossRef]

69. Corporate Governance Principles, Capital Markets Board of Turkey. 2003. Available online: http://www.cmb.gov.tr/regulations/files/corporate_governance.pdf (accessed on 15 August 2014).

70. Ararat, M.; Balic, A. Turkish Transperancy and Disclosure Survey 2008: A Year of Little or No Progress. Available online: http://research.sabanciuniv.edu/9553/1/Official_report2008.pdf (accessed on 15 August 2014).

(C) 2016 by the authors; licensee MDPI, Basel, Switzerland. This article is an open access article distributed under the terms and conditions of the Creative Commons Attribution (CC-BY) license (http:/ / creativecommons.org/licenses/by/4.0/). 